\title{
PENGARUH KUALITAS LAYANAN TERHADAP KEPUTUSAN PEMBELIAN DI CAPSULE HOTEL OLD BATAVIA, JAKARTA PUSAT
}

\author{
Dominica Luna ${ }^{1}$, Regina Dewi Hanifah ${ }^{2}$ \\ Program Studi S1 Hospitality dan Pariwisata \\ Universitas Bunda Mulia Jakarta, Indonesia \\ email: dominicaluna88@gmail.com
}

\begin{abstract}
Abstrak
Tujuan penelitian ini adalah dapat mengetahui pengaruh kualitas layanan terhadap keputusan pembelian di Capsule Hotel Old Batavia, Jakarta Pusat (simultan maupun parsial) dan dimensi yang paling berpengaruh.Penelitian ini menggunakan metode deskriptif dengan pendekatan kuantitatif jenis asosiatif kausal. Hasil penelitian yang menggunakan uji-t menunjukan bahwa dimensi tangibles, emphaty, dan reliability tidak ada pengaruh yang signifikan terhadap keputusan pembelian sedangkan untuk dimensi responsiveness dan assurance terdapat pengaruh yang signifikan terhadap keputusan pembelian dengan hasil dimensi yang paling berpengaruh adalah responsiveness. Kemudian melalui uji-F menunjukan kualitas layanan secara simultan mempengaruhi keputusan pembelian. Hasil dari nilai Adjusted $R$ Square sebesar 60,7\% menunjukan keputusan pembelian di Capsule Hotel Old Batavia, Jakarta Pusat dipengaruhi oleh variabel X (kualitas layanan) dan sebesar 39,3\% dipengaruhi faktor diluar penelitian ini.Saran yang dapat diberikan dalam penelitian ini adalah dengan meningkatkan dimensi tangibles, emphaty dan reliability. Keterbatasan dalam penelitian ini adalah 39,3\% faktor dari variabel lain yang mempengaruhi keputusan penelitian tidak dijelaskan dalam penelitian ini.
\end{abstract}

Kata Kunci:Kualitas layanan, keputusan pembelian, hotel kapsul.

\begin{abstract}
The purpose of this research was to determine the impact of service quality on purchasing decisions at Capsule Hotel Old Batavia, Central Jakarta (simultaneously or partially) and the most influential dimensions. This research uses a descriptive method with a quantitative approach to the type of associative causal. The results of the research using the t-test show that the dimensions of tangibles, empathy, and reliability have no significant effect on purchasing decisions, while for the dimensions of responsiveness and assurance there are significant effects on purchasing decisions where the most influential dimension is responsiveness. Then through the F-test shows the quality of service simultaneously influences purchasing decisions. The result of Adjusted R Square value of $60.7 \%$ indicates that the purchase decision at Capsule Hotel Old Batavia, Central Jakarta is influenced by variable $X$ (service quality), while the remaining $39.3 \%$ is explained by other variables not explained in this study. Suggestions that can be given in this study are to increase the dimensions of tangibles, empathy and reliability. The limitation in this study is that $39.3 \%$ of factors from other variables that influence research decisions are not explained in this research.
\end{abstract}

Keywords: Service Quality, Buying decisions, Capsule Hotels. 
Tren perjalanan wisata sedang melanda Indonesia dewasa ini. Masyarakatdari berbagai kalangan di Indonesia kini ramairamai melakukan perjalanan wisatake berbagai destinasi, baik di dalam negeri maupun ke luar negeri. Dari tahun ketahun terjadi peningkatan jumlah wisatawan mancanegara seperti yang dapat dilihat pada table berikut :

\section{Gambar 1}

Perkembangan Jumlah Kunjungan Wisman ke Indonesia 2017-2019

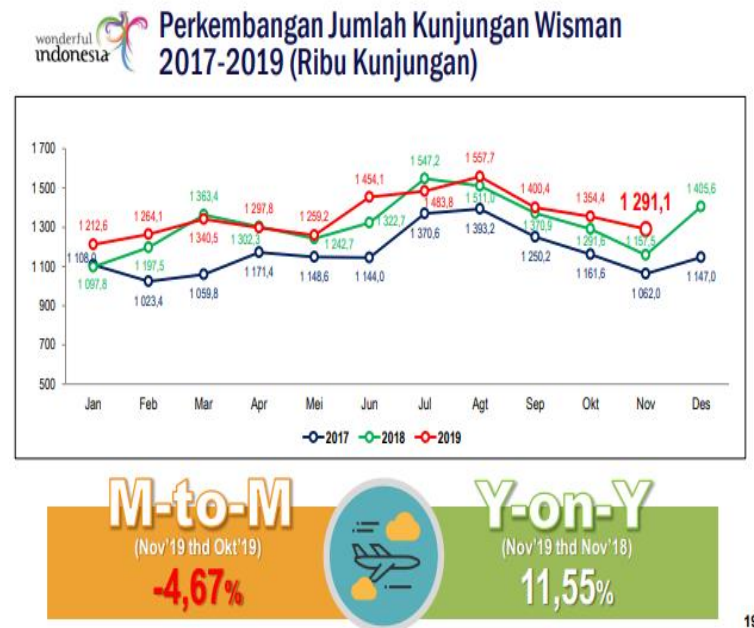

(sumber: Badan Pusat Statistik dirilis per 1 April 2019, diakses pada tanggal 12 Maret 2020)

Berdasarkan data yang di dapat dari Badan Pusat Statistik (BPS) dapat dilihat bahwa adanya kenaikan sebesar 11,55\% untuk kunjungan wisatawan mancanegara pada November 2019 dibandingkan tahun lalu. Sedangkan untuk data perbandingan dengan bulan sebelumnya yaitu Oktober 2019, di bulan November 2019 juga mengalami penurunan sebesar $4,67 \%$. Dalam perhitungan dengan kurun waktu JanuariNovember 2019, jumlah kunjungan wisata mancanegara ke Indonesianaik 3,55\% atau mencapai 14,92 juta kunjungan jika dibandingkan dengan jumlah kunjungan pada periode tahun 2018 yang berjumlah 14,40 juta kunjungan. Hal tersebut menunjukkan bahwa geliat pariwisata di Indonesia sedang berkembang belakangan ini.
Indonesia merupakan salah satu negara tujuan wisata internasional yang kaya akan keindahan alam dan ragam budayanya, dimana hal ini tentunya menarik wisatawan mancanegara untuk mengunjungi Indonesia khususnya ke beberapa kota-kota besar di Indonesia salah satunya adalah DKI Jakarta.

Seiring berjalannya waktu, tren dalam melakukan perjalanan juga bertambah, terdapat tren pada kegiatan traveling saat ini yaitu solo travel. Dikutip dari web resmi travel

tempohttps://travel.tempo.co/read/1089306/i ni-2-alasan-mengapa-solo-traveling-jaditrending/full\&view=ok (di buat pada tgl 15 Mei 2018 dan diakses pada tgl 18 maret 2020 pada) bahwa meningkatnya data pencarian terkait dengan solo travel di program SEO Google Trends sejak Februari 2012 hingga Mei 2018. Peningkatan tren ini juga sempat dijelaskan Ben Ross, Head of Prints Telegraph, dalam artikel Travel Weekly tahun 2017 mengatakan terdapat 12 persen orang yang memilih bepergian sendiri dengan keputusan bulat. Terdapat beberapa alasan mengapa para solo traveller melakukan perjalanan sendirian yaitu pertama, tidak memiliki teman yang dapat diajak melancong. Kedua, para traveller sendiri yang memilih melakukan perjalanan seorang diri.

Hal ini juga didukung oleh data dari Klook yang dikutip dari https://www.cekaja.com/info/tren-traveling2019-mana-pilihamu/ (dibuat pada tgl 19 Februari 2019 dan diakses pada tgl 7 Apil 2020) bahwa jumlah solo traveler meningkat dari $31 \%$ menjadi $385 \%$ pada tahun 2018 dan kemungkinan akan terus meningkat di tahun mendatang. Dan juga data yang dikutip dari web resmi detik.com https://travel.detik.com/travel-news/d4664172/solo-traveling-jadi-tren-anak-

milenial (dibuat pada tgl 13 Agustus 2019 dan diakses pada tanggal 10 Maret 2020 ) yaitu menurut data dari Scoot sebagai maskapai budget yang dilansir oleh detikcom pada tanggal 13 Agustus 2019 hampir 50\% generasi milenial melakukan perjalanan 
sendiri dalam periode 6 bulan pertama di tahun 2019. Dan menurut Calvin Chan, selaku Chief Commercial Officersementara di Scoot menyatakan bahwa milenial menjejakkan kaki mereka di berbagai Negara baik di Asia maupun Eropa yang menjadikan traveling sebagai salah satu gaya hidup mereka dimana hal tersebut merupakan implementasi dari kebebasan dan jiwa petualang untuk generasi tersebut.

Penelitian terbaru juga menunjukkan sebaruh dari para milenial lebih memilih untuk melakukan perjalanan seorang diri.Selain solo traveler semakin banyak wisatawan mancanegara maupun lokalyang melakukan perjalanan dengan cara backpacker. Backpackersendiri memiliki daya Tarik untuk memiliki kenikmatanhedonic dalam meningkatkan pengalaman para wisatawan dan memenuhi tingkat aktualisasi dengan terjangkau dan mudah. Sehingga tren ini semakin diminati masyarakat, didukung oleh Hecht and Martin (2006) backpacker merupakan wisatawan yang didominasi usia muda antara 15 dan 29 tahun yang berminat dengan pilihan akomodasi bertarif rendah. Walaupun wisatawan backpackers didominasi oleh pelajar dan pemuda, hal ini tidak menutup kemungkinan kegiatan backpacking dilakukan oleh wisatawan backpackers yang berusia 30 tahun keatas. Backpacker traveller yang memiliki budget lebih rendah daripada wisatawan lainya cenderung lebih cermat dalam mengatur pengeluaran biaya, oleh karena itu biaya akomodasi yang murah menjadi pilihan wajib bagi wisatawan backpackers. Namun demikian, meskipun budget berlibur wisatawan backpackers lebih rendah dibanding dengan wisatawan lainnya, wisatawan backpackers memiliki rentang berlibur lebih lama serta memiliki destinasi wisata dan negara yang jauh lebih banyak.

Dalam perkembangan pariwisata di Jakarta, seiring pula peningkatan dalam sarana dan prasarana pariwisata di Jakarta. Tentunya Jakarta sebagai Ibukota Negara juga terus mengalami perkembangan, salah satu sektor yang paling berkembang dapat terlihat dari industri akomodasi. Dan salah satu usaha akomodasi atau penginapan yang di gemari oleh backpackers adalah Hostel. Menurut Musa dan Thitumoorthi (2011) Hostel dibentuk untuk kalangan pasar wisatawan muda, menciptakan produk jasa yang mengkombinasikan jasa penginapan dengan atmosfir santai dan ramah, karena cepatnya pertumbuhan akomodasi ini diseluruh dunia, tamu hostel sekarang dianggap sebagai target segmen pasar yang penting. Hostel merupakan sebuah bisnis lodging atau penginapan bertarif rendah yang mengambil sebuah konsep shared room.

Menurut Nash dalam Gondokesumo dan Caroline (2018) dalam sebuah hostel, terdapat beberapa tipe bed yang ditawarkan sebuah hostel antara lain adalah bunk bed atau capsule bed dan dorm bed. Hal ini juga menjadi ide untuk pelaku bisnis Hostel untuk membuat sesuatu yang baru yaitu Hotel Kapsul. Menurut Widiarsana, dkk (2018) Capsule hotel memberikan fasilitas kamar yang berisi satu buah tempat tidur yang dilengkapi dengan fasilitas tambahan lainnya. Adapun letak setiap kamar bertumpuk serta berjejer memanjang dalam satu ruangan. Tentunya dalam satu ruangan besar, para tamu yang menginap akan berbagi ruangan dengan tamu lainnya. Fasilitas lainnya yang ditawarkan yaitu adanyaruang public yang dapat digunakan bersama oleh semua tamu yang menginap, sepertikamar mandi dan toilet, restoran, lounge, bahkan ruang serba guna.

Capsule hotel pertama kali dibuka di di Osaka Jepang, dengan nama Capsule Inn. Dalam pembuatannya hotel ini dirancang oleh Kisho Kurokawa, seorang arsitek asal Jepang di tahun 1972 dengan gagasan mengenai "Sebuah Hotel untuk Tahun 2001" atau, "A Hotel for the Year 2001". Di Indonesia, capsule hotelmulai sering dijumpai di Kota besar, seperti Jakarta, Bandung, Bali, Surabaya, Yogya serta Makasar.

Capsule Hotel Old Batavia adalah salah satu tipe hotel Kapsul di Jakarta yang menawarkan penginapan yang terjangkau dengan harga rata-rata permalam $\mathrm{Rp}$ 146.667; per tempat tidurnya dimana harga 
harga rata-rata hotel kapsul di Jakarta berkisar Rp. 167.427. Hal ini menjadikan Capsule Hotel Old Batavia sebagai salah satu hotel kapsul di Jakarta dengan harga rata-rata menengah kebawah sehingga mudah di jangkau oleh wisatawan khususnya backpackers. Selain itu, lokasi Capsule Hotel Old Batavia sendiri yang strategis karena berada di Jakarta Pusat dan dekat dengan stasiun kereta api Cikini membuat hostel ini diminati oleh para wisatawan karena akses transportasi yang mudah dijangkau. Capsule Hotel old Batavia juga memiliki staff yang ramah, kamar dan fasilitas yang baik terumata Rooftop Bar. Hal ini setara dengan pendapat Brady dan Cronin (2001) bahwa dalam menyusun penentu kualitas pelayanan jasa adalah kualitas interaksi yang dapatdiukur berdasarkan sikap, perilaku dan keahlian staff, kualitas lingkungan fisik yang diukur berdasarkan ambientconditions, desain serta faktor sosial dan terakhir kualitas hasil yang diukur berdasarkan waktu tunggu,valensi, dan bukti fisik.

Hal ini didukung oleh guest comment yang telah dikumpulkan dan diolah oleh peneliti dari 3 sumber yaitu Agoda, Hostelworld dan Booking.com dari periode Februari 2019 - Februari 2020 dengan produk \& layanan serta harga sebagai indicator dan mendapatkan hasil sebagai berikut:

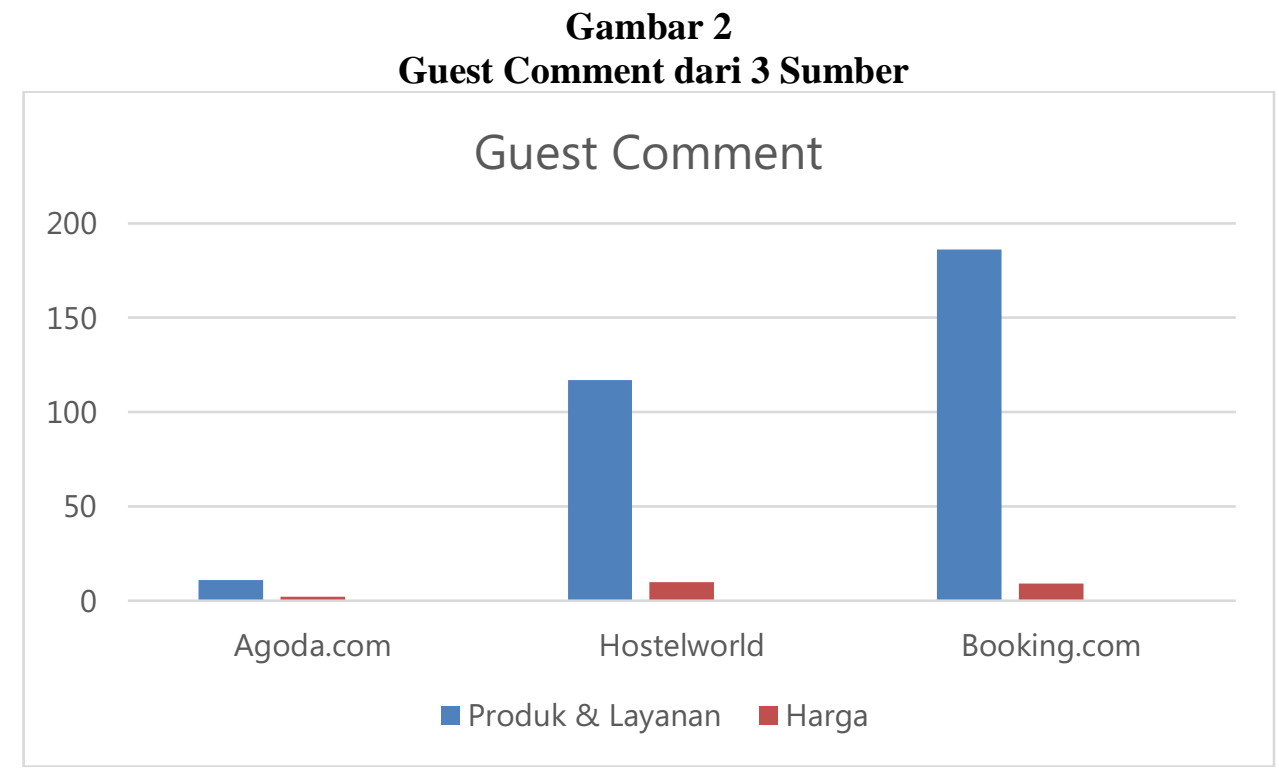

(sumber: Data diolah oleh peneliti, 2020)

Berdasarkan data tersebut dapat dilihat bahwa diantara 3 sumber tersebut, Booking.com menjadi sumber yang paling banyak di review oleh tamu. Dan dari ke dua indikator tersebut, indikator yang paling banyak di sebutkan dalam comment adalah Produk \& Layanan. Hal ini didukung oleh pendapat Parasuraman dalam Desembrianita dan Ruslin (2018) bahwa salah satu dimensi dari kualitas layanan yaitu tangible merupakan penampilan dan kemampuan sarana dan prasarana fisik perusahaan yang dapat diandalkan yang meliputi fasilitas fisik. Sehingga kualitas layanan tentu saja memegang peranan penting dalam suatu usaha, mengingat kualitas layanan yang diterapkan oleh beberapa hostel ataupun hotel kapsul lain. Menurut Kotler dalam Sangadji dan Sopiah (2013) Kualitas layanan adalah kondisi dinamis yang terpenuhi atau melebihi harapan yang berhubungan dengan produk, jasa, manusia, proses, dan lingkungan.Oleh karena itu peneliti ingin mencari tahu faktor yang mempengaruhi keputusan pembelian di Capsule Hotel Old Batavia melalui faktor kualitas layanan. 


\section{METODOLOGI}

Jenis penelitian yang digunakan adalah penelitian deskriptif dengan bentuk hubungan kasual dengan menggunakan pendekatan kuantitatif.Menurut Sugiyono (2017)hubungan kausal merupakan hubungan yang bersifat sebab akibat. Sehingga terdapat variabel independen yaitu Kualitas Layanan (X), Tangible (X1.1), Emphaty (X1.2), Reliability (X1.3), Responsiveness (X1.4), Assurance (X1.5) dan dependen (yang dipengaruhi) yaitu Keputusan Pembelian (Y).

Teknik pengumpulan data yang dilakukan penulis dalam penelitian ini menggunakan teknik pengumpulan data sebagai berikut:

\section{a. Wawancara}

Salah satu teknik pengumpulan data adalah menggunakan teknik wawancara, untuk melakukan studi pendahuluan dalam menentukan permasalahan yang akan diteliti.Selain itu digunakan juga apabila peneliti ingin mengetahui hal - hal dari responden yang lebih dalam dimana jumlah responden lebih sedikit (Sugiyono, 2017). Wawancara dalam penelitian ini dilakukan kepada pemilik ataupun staff yang bekerja di Capsule Hotel Old Batavia, Jakarta Pusat dan juga beberapa konsumen yang pernah menginap di Capsule Hotel Old Batavia, Jakarta Pusat.

\section{b. Kuesioner}

Kuesioner merupakan teknik pengumpulan data dengan cara menyusu seperangkat pertanyaan untuk diberikan kepada responden untuk dijawab (Sugiyono, 2017). Kuesioner disebarkan kepada konsumen yang telah menginap di Capsule Hotel Old Batavia, Jakarta Pusat untuk dapat mengetahui dimensi dari kualitas layanan yang paling mempengaruhi keputusan pembelian, sekaligus mengetahui apakah kualitas layanan berpengaruh terhadap keputusan pembelian di Capsule Hotel Old Batavia, Jakarta Pusat.

Data yang diperoleh melalui kuisioner berupa nilai skor, oleh karena itu pada penelitian ini, peneliti menggunakan skala likert untuk menentukan skor pilihan jawaban kuisioner. Menurut Hadi dalam Putra (2019) modifikasi dalam skala likert ditujukan untuk menghilangkan kelemahan yang terdapat skala lima tingkat yang menimbulkan kecenderungan jawaban ke tengah atau biasa disebut central tendency effect, terutama bagi mereka yang ragu kea rah setuju dan tidak setuju. Tujuan dari modifikasi ini adalah untuk meningkatkan banyaknya informasi yang dapat dijaring dari responden dengan mengurangi kategori tersebut.

Oleh karena itu, instrumen yang dikembangkan dengan menggunakan skala likert dengan menggunakan 4 skala oleh peneliti, yaitu Sangat Setuju (SS), Setuju (S), Tidak Setuju (TS), Sangat Tidak Setuju (STS), dengan menghilangkan alternative jawaban Ragu-ragu (R) yang biasa dipilih oleh orang yang tidak memilih jawaban yang ekstrim.

\section{c. Observasi}

Berdasarkan Sugiyono (2017), Observasi merupakan teknik pengumpulan data denganciriyang lebih spesifik dibandingkan dengan teknik yang lain. Observasi dapat dilakukan dengan melihat langsung di lapangan dalam menentukan serta mengidentifikasi faktor yang akan diteliti didukung teknik wawancara.

\section{d. Penelitian Kepustakaan (Library Research)}

Penelitian kepustakaan yaitunteknik pengumpulan data untuk memperoleh data sekunder dengan menggunakan studi literatur untuk memperoleh dasar teoritis dalam pemecahan masalah yang diteliti (Sugiyono, 2017). Data dari literatur memiliki manfaat sebagai bahan pertimabangan atas data yang telah diperoleh dari penelitian.

\section{e. Riset Internet (Online Research)}

Menurut Sugiyono (2017)riset internet merupakan teknik dalammengumpulkan data yang berhubungan dengan berbagai 
informasi yang dibutuhkan dalam penelitian dari situs-situs atau website yang dilakukan dengan memanfaatkan jaringan internet dan situs.

Dalam penelitian ini teknik sampling yang digunakan yaitu non-probability samplingdengan teknik purposive sampling..Dengan menggunakan populasi seluruh konsumen yang sudah menginap di Capsule Hotel Old Batavia, Jakarta Pusat sejak tahun 2014-2020. Untuk sampel yang digunakan sebesar 85 sampel responden yang didapat menggunakan teori Sli, dimana jumlah sampel bergantung pada jumlah indikator yang digunakan dalam seluruh variabel bentukan, yang dikali 5-10.

\section{RESULT AND DISCUSSION}

Capsule Hotel Old Batavia adalah hotel backpacker yang sudah berdiri sejak Juli 2014 yang menjadi favorit para travelersmancanegara yang terletak di Cikini, Jakarta Pusat dan mengutamakan akomodasi yang berbentuk Capsule. Menjadi yang terdepan untuk bertemu dan mengenal para turis / backpacker mancanegara karena lokasi yang strategis dan terletak di pusat kota, juga dekat dengan tempat wisata seperti Planetarium, Taman Ismail Marzuki, Cikini Gold Center, dll. Untuk jam operasional, Capsule Hotel Old Batavia buka dari jam 7 pagi sampai jam 12 malam setiap harinya.

Capsule Hotel Old Batavia merupakan salah satu tempat rekomendasi untuk para backpacker yang tidak mengutamakan biaya, tetapi juga kenyamanan dalam fasilitas. Mengemas produk dengan harga yang sesuai dengan marketnya, hotel ini menyediakan fasilitas dan pelayanan yang tetap terjaga mutunya. Adapun desain, atmosfir dan juga keunikan dari bentuk hotel menjadi salah satu hal penentu dalam memilih akomodasi dan didukung kesiapan tim resepsionis yang selalu hadir 24 jam dalam melayani proses guest cycle lainnya untuk tamu.

Penyajian data pada penelitian ini berasal dari kuesioner yang telah disebar kepada 85 (delapan puluh lima) responden yang merupakan konsumen / tamu yang pernah menginap di Capsule Hotel Old Batavia, Jakarta Pusat yang disebar mulai dari $18 \mathrm{Mei}$ 2020 hingga 22 Mei 2020. Penyebaran kuesioner ini menggunakan google form dengan menyebarkan link google form tersebut kepada responden melalui social media seperti Instagram dan juga menggunakan aplikasi seperti Whatsapp. Responden dapat langsung mengisi dengan memilih pilihan jawaban sesuai denngan yang disediakan. Jumlah responden yang terkumpul adalah 85 (delapan puluh lima) responden dengan populasinya adalah seluruh konsumen yang pernah menginap di Capsule Hotel Old Batavia, Jakarta Pusat serta adanya wawancara yang dilakukan dengan pihak hotel yaitu dengan Bapak Ersa selaku Operation Manager di Capsule Hotel Old Batavia, Jakarta Pusat melalui Whatsapp call pada Kamis, 28 Mei 2020 dan juga wawancara dengan tamu yaitu Rohana Humulyani melalui direct message Instagram pada Sabtu, 30 Mei 2020.

Tabel1

Tabelalasan utamaresponden menginap di Capsule Hotel Old Batavia, Jakarta Pusat

\begin{tabular}{|c|c|c|}
\hline Alasan utama responden menginap & Responden & Persentase \\
\hline Rekomendasi orang lain & 30 & $35.30 \%$ \\
\hline Pelayanan yang baik & 24 & $28.20 \%$ \\
\hline Fasilitas yang baik & 14 & $16.50 \%$ \\
\hline Akses mudah di jangkau & 11 & $12.90 \%$ \\
\hline Lainnya & 6 & $7.10 \%$ \\
\hline Total Responden & $\mathbf{8 5}$ & $\mathbf{1 0 0 \%}$ \\
\hline
\end{tabular}


(Sumber: Data Primer yang telah diolah peneliti, 2020)

Berdasarkan sumber data yang diambil dari 85 responden, dari tamu yang menginap di Capsule Hotel Old Batavia, Jakarta Pusat yang menginap dengan alasan Rekomendasi dari orang lain berjumlah 30 orang atau dengan persentase $35.30 \%$, yang menginap karena alasan Pelayanan yang baik berjumlah 24 orang atau dengan persentase $28.20 \%$, yang menginap karena alasan Fasilitas yang baik berjumlah 14 orang atau dengan persentase $16.50 \%$, yang menginap karena alasan Akses mudah dijangkau berjumlah 11 orang atau dengan persentase $12.90 \%$ dan yang menginap karena alasan Lainnya berjumlah 6 orang atau dengan persentase $\quad 7.10 \%$.Sehingga dapat disimpulkan bahwa tamu yang menginap di Capsule Hotel Old Batavia, Jakarta Pusat lebih didominasi oleh tamu yang menginap dengan alasan Rekomendasi dari orang lain yang berjumlah 30 orang atau dengan persentase $35.30 \%$. Hal ini didukung oleh pendapat dari Rohana Humulyani selaku tamu yang pernah menginap di Capsule Hotel Old Batavia, Jakarta Pusat bahwa dirinya menginap karena mendapat rekomendasi dari teman nya.

Berdasarkan sumber data yang diambil dari 85 responden, dari tamu yang menginap di Capsule Hotel Old Batavia, Jakarta Pusat yang mengetahui informasi mengenai Capsule Hotel Old Batavia, Jakarta Pusat dari Publik (media social, internet, dll)berjumlah 70 tamu atau dengan persentase $82.40 \%$ sedangkan yang mengetahui informasi mengenai Capsule
Hotel Old Batavia, Jakarta Pusat dari Pribadi ( teman, keluarga, dll)berjumlah 15 tamu atau dengan persentase $17.60 \%$, Sehingga dapat disimpulkan bahwa tamu yang menginap di Capsule Hotel Old Batavia, Jakarta Pusat lebih didominasi oleh tamu yang mengetahui informasi mengenai Capsule Hotel Old Batavia, Jakarta Pusat dari Publik (media social, internet, dll)berjumlah 70 tamu atau dengan persentase $82.40 \%$. sehingga hal tersebut sesuai dengan promosi yang dilakukan oleh pihak Capsule Hotel Old Batavia, Jakarta Pusat. Menurut Bapak Ersa selaku Operation Manager Capsule Hotel Old Batavia, Jakarta Pusat, promosi yang sudah dilakukan adalah melalui social media berupa Instagram.

\section{Hasil Uji Regresi Linear Berganda}

Berdasarkan Sugiyono (2017), metode analisis yang digunakan dalam menentukan ketepatan dalam memprediksi pengaruh antara variable independen(X) terhadap variable dependen (Y)dapat menggunakan analisis regresi berganda. Berikut adalah hasil dari uji regresi linear berganda untuk pengaruh kualitas layanan terhadap kepuasan pembelian dengan menggunakan program SPSS.

Tabel 2 Hasil Uji Regresi Linear Berganda Coefficients $^{a}$

\begin{tabular}{|c|c|c|c|c|c|c|}
\hline \multirow[b]{2}{*}{ Model } & & \multicolumn{2}{|c|}{ Unstandardized Coefficients } & \multirow{2}{*}{$\begin{array}{c}\text { Standardized } \\
\text { Coefficients } \\
\text { Beta }\end{array}$} & \multirow[b]{2}{*}{$\mathrm{t}$} & \multirow[b]{2}{*}{ Sig. } \\
\hline & & B & Std. Error & & & \\
\hline 1 & (Constant) & 6.519 & 2.371 & & 2.750 & .007 \\
\hline & Tangibles & .114 & .094 & 119 & 1.212 & .229 \\
\hline & Emphaty & .312 & .247 & .131 & 1.263 & .210 \\
\hline & Responsiveness & 1.011 & .235 & .520 & 4.295 & .000 \\
\hline & Reliability & -.217 & .155 & -.189 & -1.396 & .167 \\
\hline & Assurance & .397 & .142 & .311 & 2.789 & .007 \\
\hline
\end{tabular}

a. Dependent Variable: Keputusan Pembelian 
(Sumber: Hasil pengolahan data SPSS, 2020)

Dari hasil pengolahan analisis regresi linear berganda yang telah dilakukan, maka dapat disusun persamaan regresi sebagai berikut:

$$
\begin{aligned}
& \mathrm{Y}=\mathrm{a}+\mathrm{b} 1 \mathrm{X} 1+\mathrm{b} 2 \mathrm{X} 2+\mathrm{b} 3 \mathrm{X} 3+\mathrm{b} 4 \mathrm{X} 4+ \\
& \mathrm{b} 5 \mathrm{X} 5+\mathrm{e} \\
& \quad=6,519+0,114 \mathrm{X} 1+0,312 \mathrm{X} 2+1,011 \\
& \mathrm{X} 3+(-0,217) \mathrm{X} 4+0,397 \mathrm{X} 5+\mathrm{e}
\end{aligned}
$$

Berdasarkan persamaan regresi tersebut, dapat dijabarkan sebagai berikut:

1. Nilai a atau konstanta sebesar 6,519 dapat dinyatakan sebagai berikut:

Apabila variabel tangibles (X1), reliability (X2), responsiveness (X3), assurance (X4), dan empathy (X5)sama dengan (0), maka nilai keputusan pembelian (Y) sebesar 6,519 .

2. Koefisien regresi variabel tangibles (b1) sebesar 0,114bernilai positif. Hal ini menunjukkan bahwa jika tangibles ditingkatkan 1 satuan, keputusan pembelian akan naik sebesar 0,114. Apabila variabel tangible ditingkatkan maka variabel keputusan pembelian juga semakin meningkat.

3. Koefisien regresi variabel emphaty (b2) sebesar 0,312bernilai positif. Hal ini menunjukkan bahwa jika emphaty ditingkatkan 1 satuan, keputusan pembelian akan naik sebesar 0,312. Bila variabel emphaty ditingkatan maka variabel keputusan pembelian juga semakin meningkat.

4. Koefisien regresi variabel responsiveness (b3) bernilai positif sebesar 1,011. Hal ini menunjukkan bahwa jika variabel responsiveness ditingkatkan 1 satuan, maka nilai variabel keputusan pembelian akan naik sebesar 1,011. Nilai positif diartikan apabila variabel responsivenessditingkatan maka variabel keputusan pembelian juga semakin meningkat.
5. Koefisien regresi variabel reliability (b4) bernilai negatif(-0,217).Nilai ini menunjukkan bahwa jika variabel assurance tidak ditingkatkan 1 satuan, maka nilai variabel keputusan pembelianturun sebesar $(-0,217)$. Nilai negatif diartikan apabila variabel reliabilitytidak ditingkatan maka keputusan pembelian akan menurun.

6. Koefisien regresi variabel assurance (b5) bernilai positif 0,397. Hal ini menunjukkan bahwa jika vector assurance ditingkatkan 1 satuan, maka keputusan pembelian akan naik sebesar 0,397. Nilai positif diartikan apabila variabel assurance ditingkatan maka keputusan pembelian akan semakin meningkat.

\section{Hasil Uji T}

Uji t berdasarkan Ghozali (2018) digunakan untukmenunjukkan seberapa jauh pengaruh satu variabel independen secara individual dalam menerangkan variabel dependen. Berdasarkan Sugiyono (2017) dalam uji t dapat menggunakan kriterianya sebagai berikut:

a. Jika $t$ hitung $>$ ttabel pada $\alpha=5 \%$ atau thitung $<$ ttabel atau $\mathrm{P}$ value (sig) $<\alpha$ maka Ho ditolak dan H1 diterima (berpengaruh).

b. Jika thitung $<$ ttabel pada $\alpha=5 \%$ atau thitung $>$ ttabel atau $\mathrm{P}$ value (sig) $>\alpha$ maka Ho diterima dan $\mathrm{H} 1$ ditolak (tidak berpengaruh).

Penelitian ini menggunakan data dengan 85 responden didapatkan dari pembulatan hasil derajat kebebasan (degree of freedom) sebesar 84 orang dengan penggunaan tingkat signifikasi sebesar 5\% atau 0,05. Berdasarkan Sugiyono (2015) untuk mengetahui derajat kebebasan menggunakan rumusdf $=n-2$, yang dimana $n$ adalah jumlah responden sehingga pada penelitian ini Sehingga berdasarkan dari nilai degree of freedom dan nilai tingkat signifikasi dapat 


\begin{tabular}{|c|c|c|c|c|c|c|}
\hline \multirow[b]{3}{*}{ Model } & \multicolumn{6}{|c|}{$\begin{array}{c}\text { Tabel } 3 \text { Hasil Uji T } \\
\text { Coefficients }^{\mathbf{a}}\end{array}$} \\
\hline & & \multicolumn{2}{|c|}{ Unstandardized Coefficients } & \multirow{2}{*}{$\begin{array}{c}\text { Standardized } \\
\text { Coefficients } \\
\text { Beta } \\
\end{array}$} & \multirow[b]{2}{*}{$\mathrm{t}$} & \multirow[b]{2}{*}{ Sig. } \\
\hline & & $\mathrm{B}$ & Std. Error & & & \\
\hline \multirow[t]{6}{*}{1} & (Constant) & 6.519 & 2.371 & & 2.750 & .007 \\
\hline & Tangibles & .114 & .094 & .119 & 1.212 & .229 \\
\hline & Emphaty & .312 & .247 & .131 & 1.263 & .210 \\
\hline & Responsiveness & 1.011 & .235 & .520 & 4.295 & .000 \\
\hline & Reliability & -.217 & .155 & -.189 & -1.396 & .167 \\
\hline & Assurance & .397 & .142 & .311 & 2.789 & .007 \\
\hline
\end{tabular}

a. Dependent Variable: Keputusan Pembelian

(Sumber: Hasil pengolahan data SPSS, 2020)

Berdasarkan tabel di atas nilai signifikansi thitung sebagai berikut:

1. Nilai t hitung variabel tangible sebesar $1,212<$ ttabel 1,988 dengan nilai signifikan $0,229>0,05$ maka $\mathrm{H} 1$ ditolak. Dapat disimpulkan untuk variable tangible tidak berpengaruh signifikan terhadap keputusan pembelian.

2. Nilai t hitung variabel emphaty sebesar $1,263<\mathrm{t}$ tabel 1,988 dengan nilai signifikan 0,210>0,05 maka H2ditolak. Dapat disimpulkan untuk variabel emphaty tidak berpengaruh signifikan terhadap keputusan pembelian.

3. Nilai $\mathrm{t}$ hitung variabel responsiveness adalah 4,295 > t tabel 1,988 dengan nilai signifikan $0,000<0,05$ maka $\mathrm{H} 3$ dapat diterima. Sehingga disimpulkan bahwa variabel responsivedapat berpengaruh signifikan terhadap keputusan pembelian.

4. Nilai t hitung untuk variabel reliability adalah(-1,396) < t tabel 1,988 dengan nilai signifikan $0,167>0,05$ maka H4ditolak. Sehingga disimpulkan bahwa variabel reliability tidak berpengaruh signifikan terhadap keputusan pembelian.
5. Nilai $t$ hitung untuk variabel assurancedengan nilai signifikan 0,007 < 0,05 memiliki nilai sebesar 2,789 > t tabel 1,988maka H5 diterima. Sehingga simpulan dari nilai tersebut adalah variabel assurance berpengaruh signifikan terhadap keputusan pembelian.

Sehingga dari penjabaran diatas dapat disimpulkan bahwatidak terdapat pengaruh yang signifikan untuk dimensitangibles, emphhaty, dan reliability terhadap keputusan pembelian, sedangkan untuk dimensiresponsiveness dan assurance memiliki pengaruh yang signifikan terhadap keputusan pembelian. Selain itu, berdasarkan hasil analisisi diatas, dimensi yang paling berpengaruh terhadap keputusan pembelianadalah dimensiresponsiveness. Hal ini bisa terjadi karena mayoritas tamu yang menginap di Capsule Hotel Old Batavia, Jakarta Pusat setuju bahwa staff yang bekerja di Capsule Hotel Old Batavia, Jakarta Pusat yang memiliki tingkat responsive tinggi dalam mengatasi kesulitan yang dialami tamu, dam juga memberikan pelayanan yang cepat, serta memberikan informasi dengan jelas dan mudah dimengerti. Selaras dengan pernyataan Bapak Ersa selaku Operational Manager di Capsule Hotel Old Batavia, Jakarta Pusat bahwa bila terdapat kesulitan yang dialami oleh tamu pihaknya akan sebisa 
mungkin membantu. Pihak Capsule Hotel Old Batavia, Jakarta Pusat pun memiliki standar kecepatan dan memberikan target waktu dalam tersendiri terutama pada House Keeping dalam membersihkan area hotel dan kamar. Selain itu, dalam berkomunikasi pihak Capsule Hotel Old Batavia, Jakarta Pusat memiliki staff yang dapat berkomunikasi dalam Bahasa inggris, bila terdapat kendala Bahasa staff akan menggunakan google translate.

\section{Hasil Uji F}

Uji simultan F menurut Ghozali (2018)dapat digunakan untuk mengetahui apakah ada pengaruh secara bersama-sama antara variabel-variabel independen terhadap variabel dependen.

Untuk menghitung Ftabel adalah dengan rumus berikut:

df $1=\mathrm{k}-1$

$\mathrm{df} 2=\mathrm{n}-\mathrm{k}$

Keterangan:

$\mathrm{k}=$ jumlah variabel (bebas + terikat)

$\mathrm{n}=$ jumlah observasi/sampel pembentuk regresi.

Sehingga:

df $1=2-1=1$

df $2=85-2=83$

Sehingga didapatkan Hasil uji $\mathrm{F} t$ table sebesar 3,96(berdasarkan lampiran F table).

\begin{tabular}{|c|c|c|c|c|c|c|}
\hline \multicolumn{7}{|c|}{$\begin{array}{c}\text { Tabel 4Hasil Uji F } \\
\text { ANOVA }^{\mathrm{a}}\end{array}$} \\
\hline Model & & $\begin{array}{l}\text { Sum of } \\
\text { Squares }\end{array}$ & df & Mean Square & $\mathrm{F}$ & Sig. \\
\hline \multirow[t]{3}{*}{1} & Regression & 391.165 & 5 & 78.233 & 24.370 & $.000^{\mathrm{b}}$ \\
\hline & Residual & 253.612 & 79 & 3.210 & & \\
\hline & Total & 644.776 & 84 & & & \\
\hline
\end{tabular}

(Sumber: Hasil pengolahan data SPSS, 2020)

Berdasarkan table diatas dapat dilihat nilai signifikansi nya adalah sebesar 0.000 . Sehingga dapat diambil kesimpulan untuk dimensi kualitas layanan yang terdiri dari tangible, emphaty, responsiveness, reliability dan assurance secara simultan mempengaruhi keputusan pembelian dengan nilai signifikansi $0.000<0.05$ atau dengan hasil Fhitung $(24.370>3.96)$.

\section{Hasil Uji Koefisien Korelasi Product Moment}

Dalam bukunya Sugiyono (2017) menyatakan bahwa penggunaan analisis koefisien korelasi dapat digunakan dalam mengetahui arah dan kuatnya hubungan antar dua variabel atau lebih.Koefisien korelasi (r) memperlihatkan derajat korelasi antara variabel satu dan lainnya. Nilai koefisien korelasi harus terdapat dalam batas-batas -1 hingga $+1(-1<\mathrm{r} \leq+1)$. Dimana bila nilai korelasi ${ }^{\circledR}$ berkisar antara 1 sampai -1 , nilai semakin mendekati 1 atau -1 berarti hubungan antara dua variabel semakin kuat, sebaliknya bila nilai mendekati 0 maka hubungan antara dua variabel semakin lemah. Nilai Positif memperlihatkan hubungan searah (Bila nilai $X$ naik maka $Y$ naik) dan sebaliknya yaitu nilai negative dimana menunjukan hubungan (Bila $\mathrm{X}$ naik maka Y turun)

Dapat dilihat dari table dibawah bahwanilai korelasi dihasilkan 0,779 yang masuk kedalam kategori "Tinggi" $(0,60-0,799)$ sehingga simpulan untuk penelitian ini adalah adanya hubungan atau korelasi yang tinggi antara kualitas layanan terhadap keputusan pembelian di Capsule Hotel Old Batavia, Jakarta Pusat. 
Tabel 5 Hasil Koefisien Korelasi Product Moment

$$
\text { Model Summaryb }
$$

\begin{tabular}{|c|c|c|c|c|}
\hline \multicolumn{5}{|c|}{ 与 } \\
\hline Model & $\mathrm{R}$ & R Square & $\begin{array}{l}\text { Adjusted R } \\
\text { Square }\end{array}$ & $\begin{array}{c}\text { Std. Error of the } \\
\text { Estimate }\end{array}$ \\
\hline 1 & $.779^{a}$ & .607 & .582 & 1.792 \\
\hline
\end{tabular}

(Sumber: Hasil pengolahan data SPSS, 2020)

\section{Koefisien Determinasi $\left(\mathbf{R}^{\mathbf{2}}\right)$}

Penggunaan Uji koefisien determinasi $\left(\mathrm{R}^{2}\right)$ ditujukan untuk memprediksi berapa tingkat kontribusi pengaruh variabel independen terhadapvariabel dependen berdasarkan Ghozali (2018). Hasil nilai koefisien determinasi sendiri adalah antara nol dan satu, dimana nilai yang mendekati satu berartii variabel-variabel independen memberikanhampir semua informasi yang dibutuhkan dalam memprediksi variable dependen. Dan berlaku sebaliknya, bila nilai koefisien determinasi kecil, maka hal tersebut menandakan kemampuan variabel independen dalam menjelaskan variasi variabel dependen terbatas. Berikut merupakan hasil uji Korelasi Determinasi:

Tabel 6 Hasil Koefisien Determinasi Model Summary ${ }^{b}$

\begin{tabular}{|c|c|c|c|c|}
\hline \multirow{2}{*}{\multicolumn{4}{|c|}{ 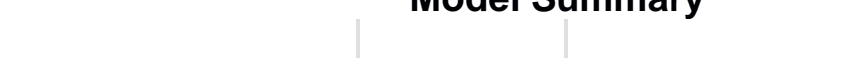 }} & \multirow[b]{2}{*}{$\begin{array}{c}\text { Std. Error of the } \\
\text { Estimate }\end{array}$} \\
\hline & & & & \\
\hline 1 & $.779^{a}$ & .607 & .582 & 1.792 \\
\hline
\end{tabular}

(Sumber: Hasil pengolahan data SPSS, 2020)

Dapat dilihat dari table diatas bahwa nilai $\mathrm{R}$ square atau koefisien determinasi sebesar 0,607 yang didapatkan dari hasil penelitian dengan menggunakan 85 responden, nilai tersebut menjadi $60,7 \%$ dengan menggunakan rumus $\mathrm{Kd}=\mathrm{R} 2 \times 100 \%$. Berdasarkan hasil tersebut dapat disimpulkan bahwa $60,7 \%$ keputusan pembelian di Capsule Hotel Old Batavia, Jakarta Pusat dipengaruhi oleh variable $\mathrm{X}$ yaitu tangibles, reliability, responsiveness, assurance dan empahty sedangkan sebesar 39,3\% dapat dijelaskan oleh variabel lain diluar penelitian ini. Sehingga dapat disimpulkan bahwa pengaruh cukup besar dnegan hasil koefisien determinasi lebih dari 50\% yang dimiliki variabel $\mathrm{X}$ yaitu tangibles, reliability, responsiveness, assurance danempathy terhadap keputusan pembelian.

\section{KESIMPULAN}

Berdasarkan hasil pengolahan data yang telah dilakukan oleh peneliti dalam penelitian pengaruh kualitas layanan terhadap keputusan pembelian di Capsule Hotel Old Batavia, Jakarta Pusat didapatkan kesimpulan untuk rumusan masalah sebagai berikut:

a. Pada pengujian regresi linear berganda dapat disimpulkan bahwa apabila variabel tangible, emphaty, responsiveness dan assurance ditingkatkan maka keputusan pembelian juga meningkat, sedangkan apabila variabel reliability tidak ditingkatkan maka variabel keputusan pembelian akan menurun.

b. Pada uji $\mathrm{T}$ dapat di simpulkan bahwa variabel tangibles, emphaty, dan reliability tidak terdapat pengaruh signifikan terhadap keputusan pembelian. 
Sedangkan untuk variabel responsiveness dan assurance terdapat pengaruh signifikan terhadap keputusan pembelian.Dimana berdasarkan hasil uji, dimensi yang paling berpengaruh terhadap keputusan pembelian merupakan dimensi responsiveness. Hal ini bisa terjadi karena mayoritas tamu yang menginap di Capsule Hotel Old Batavia, Jakarta Pusat setuju bahwa staff yang bekerja di Capsule Hotel Old Batavia, Jakarta Pusat selalu bersedia membantu tamu dalam mengatasi kesulitan, juga memberikan pelayanan yang cepat tamggap, ditambah dengan memastikan informasi yang diberikan sudah jelas dan mudah dimengerti. Didukung dengan pernyataan Bapak Ersa selaku Operational Manager di Capsule Hotel Old Batavia, Jakarta Pusat bahwa bila terdapat kesulitan yang dialami oleh tamu pihaknya akan sebisa mungkin membantu, pihak Capsule Hotel Old Batavia, Jakarta Pusat juga memiliki staff yang dapat berkomunikasi dalam Bahasa inggris, bila terdapat kendala Bahasa staff akan menggunakan google translate.

c. Pada Uji $\mathrm{F}$ diperoleh hasil bahwa nilai signifikansi nya adalah sebesar 0.000 . Sehingga dapat diambil kesimpulan bahwa kualitas layanan secara simultan mempengaruhi keputusan pembelian

d. Nilai Uji Korelasi Product Momentmasuk kedalam kategori "Tinggi”" $(0,60-0,799)$ dengan nilai 0,779 , sehingga dapat disimpulkan oleh peneliti bahwa adanya hubungan atau korelasi yang tinggi antara kualitas layanan terhadap keputusan pembelian di Capsule Hotel Old Batavia, Jakarta Pusat.

e. Nilai Uji Koefisien Determinasi pada penelitian ini adalah 0,607 atau $60,7 \%$. Dan dapat diartikan bahwa 60,7\% keputusan pembelian di Capsule Hotel Old Batavia, Jakarta Puast dipengaruhi oleh variabel $\mathrm{X}$ yaitu tangibles, reliability, responsiveness, assurance dan empahty.Sedangkan sebesar 39,3\% dapat dijelaskan oleh variabel lain yang tidak diuji dalam penelitian ini.

\section{SARAN}

Saran untuk dapat meningkatkan lagi keputusan pembelian di Capsule Hotel Old Batavia, Jakarta Pusat dengan memperbaiki variabel tangiblesyaitu agar dapat menyediakan fasilitas untuk tamu yang muslim seperti yang disampaikan oleh Kak Rohana bahwa tidak terdapat fasilitas untuk tamu yang muslim seperti perlengkapan sholat ataupun musholla, untuk dimensi emphatydapat ditingkatkan dengan lebih memahami kebutuhan tamu seperti perlengkapan dan kebutuhan rohani seperti beribadah, danuntuk dimensi reliabilitydapat ditingkatkan proses check-in dan check-out, Kak Rohana berpendapat bahwa prosesnya sedikit lebih lama dari hoteldikarenakan dimensi-dimensi tersebut tidak terdapat pengaruh yang signifikan terhadap keputusan pembelian di Capsule Hotel Old Batavia, Jakarta Pusat. Serta mempertahankan bahkan meningkatkan lagi dimensiresponsiveness dan assurance walaupun dimensi tersebut sudah terdapat pengaruh yang signifikan terhadap keputusan pembelian di Capsule Hotel Old Batavia.Adapun keterbatasan untuk penelitian ini adalah wabah covid-19 yang melanda yang menyebabkan Capsule Hotel Old Batavia, Jakarta Pusat tutup sementara sampai waktu yang belum ditentukan oleh karena itu peneliti tidak dapat melakukan observasi ataupun wawancara secara langsung. Serta faktor lainnya yang dapat mempengaruhi keputusan pembelian diluar faktor kualitas layanan yang tidak diteliti dalam penelitian ini.

\section{DAFTAR PUSTAKA}

Arikunto, S.(2016). Prosedur Penelitian: Suatu Pendekatan Praktik. Jakarta: Rineka Cipta

Buchari, A. (2011). Manajemen Pemasaran dan Pemasaran Jasa. Bandung: Alfabeta 
Daryanto, (2013). Inovasi Pembelajaran Efektif. Bandung: Yrma Widya

Kotler dan Gary Amstrong. (2016). Dasardasar Pemasaran .Jilid 1, Edisi Kesembilan. Jakarta: Erlangga.

Kotler, Philip and Kevin Lane Keller, (2016).Marketing Management, 15th Edition. New Jersey: Pearson Pretice Hall, Inc.

Muljadi, A.J. (2012).Kepariwisataan dan Perjalanan. Jakarta: PT Raja Grafindo Persada

Noor, J. (2012). Metodologi Penelitian Skripsi, Tesis dan Disertai Karya ilmiah. Cetakan Kedua. Jakarta: Kencana Prenada Media.

Sugiyono.(2017). Metode Penelitian Kuantitatif, Kualitatif, dan $R \& D$. Bandung: CV Alfabeta

Tjiptono, Fandy \& Chandra, G. (2012). Pemasaran Strategik.Edisi Kedua Yogyakarta:ANDI.

Tjiptono, Fandy Diana, Anastasia. (2016). Pemasaran Esesi dan Aplikasi, Yogyakarta:ANDI

Audina, Nia. (2018). Kualitas Pelayanan Room Boy Di Hotel Grand Zuri Pekanbaru Riau. JOM FISIP Vol. 5 No. 1, April. Riau: Universitas Riau

Badan Pusat Statistik.(2020).Perkembangan Pariwisata dan Transportasi Nasional No. 03/01/Th. XXIII, Jakarta: Badan Pusat Statistik

Baeti, Destiana. (2018). Pengaruh Kualitas Pelayanan Terhadap Kepuasan Tamu Di Hotel Niagara Parapat Provinsi Sumatera Utara. JOM FISIP Vol. 5 No. 1 - April. Riau: Universitas Riau

Ghozali, I. (2016). Aplikasi Analisis Multivariete Dengan Program IBM SPSS 23 Edisi 8. Semarang: Badan Penerbit Universitas Diponegoro.

Ghozali, I. (2018). Aplikasi Analisis Multivariate Dengan Program IBM SPSS 25. Semarang: Badan Penerbit Universitas Diponegoro.
Musa dan Thitumoorthi.(2011). Red Palm: Exploring Service Quality and Servicescape of the best backpacker hostel in Asia. Current issues in Tourism. Volume 4.

Putra, Ali Syah. (2019). Analisis Pengaruh Budaya Organnisasi Terhadap Kinerja Karyawan CV Wira Sukses Jaya Medan. Jurnal Ilmiah Skylandsea Vol 3 No 2

Suwithi, Ni Wayan \& Boham, Cecil Erwin Jr. (2008). Akomodasi Perhotelan. Jakarta; Direktorat Pembinaan Sekolah Menengah Kejuruan, Direktorat Jenderal Manajemen Pendidikan Dasar dan Menengah, Departemen Pendidikan Nasional.

Ali, Syah Baginda. (2016). Strategi Pengembangan Fasilitas Guna Mengingkatkan Daya Tarik Minat Wisatawan Di Darajat Pass (Waterpark) Kecamatan Pasirwangi Kabupaten Garut. Bandung: Universitas Pendidikan Indonesia.

Brahmisiwi, Ida Ayu Shintyani. (2015). Pengaturan Investasi Semi Kelola Di Bidang Perdagangan Jasa Akomodasi Wisata. Denpasar: Universitas Udayana.

Desembrianita, Eva dan Ruslin. (2016). Pengaruh Kualitas Pelayanan, Fasilitas, Dan Harga Terhadap Keputusan Pelanggan Untuk Menggunakan Jasa Hotel Oval Surabaya. Surabaya: Sekolah Tinggi Ilmu Ekonomi Urip Sumoharjo Surabaya.

Gondokesumo, Reyner dan Caroline, Novia.(2018).Pengaruh Bauran Pemasaran Terhadap Keputusan Pembelian Wisatawan Backpacker Dalam Memilih Sebuah Hostel Di Bali. Surabaya: Universitas Kristen Petra. 
(p- ISSN 1858-0112, e-ISSN 15537-37677)http://jurnal.unmuhiember.ac.id/index.php/wisata

Lukita, Andreas. (2017). Pengaruh Kualitas Pelayanan Terhadap Keputusan Pelanggan Menginap Pada Hotel Duta di Lampung Utara. Lampung: Universitas Lampung

Rahma, Fajar Nuur Alfie. (2017). Desain interior Budget Hotel Untuk Backpacker Dengan Konsep Persahabatan Asia. Surabaya: Institut Teknologi Sepuluh Nopember.

Sulanjari, Bintang. (2018). Analisis Pengaruh Kesadaran Harga, Persepsi Nilai, Dan Kepuasan Wisatawan Terhadap Niat Perilaku Berbelanja Produk Imitasi Di Malioboro. Yogyakarta: Universitas Islam Indonesia

Sulistiono, Ari Budi. (2010). Pengaruh Kualitas Pelayanan, Fasilitas dan Lokasi terhadap Keputusan Menginap (Studi Kasus Pada Tamu Hotel Srondol Indah Semarang). Semarang: Universitas Diponegoro

Utami, Vonny Dwi. (2016). Perancangan Buku Panduan Tentang Solo Traveling. Tangerang: Universitas Multimedia Nusantara.

Widiarsani, Ni Made. Sulistyawati, Agung Sri. Aryanti, Ni Nyoman Sri. (2018).Identifikasi dan persepsi wisatawan terhadap capsule hotel di kuta bali, Bali: Universitas Udayana.

Undang Undang RI tentang Kepariwisataan, No. 10 Tahun 2009. Jakarta: Menteri Sekretaris Negara

Undang Undang RI tentang Kepariwisataan, No. 10 Pasal 14 Ayat 1 Tahun 2009. Jakarta: Menteri Sekretaris Negara.

http://data.jakarta.go.id/group/b6dd7cd44e63-462c-b7d6df89e2922bd0?organization=dinaspariwisata\&page $=2$ (dibuat pada tgl 5
Februari 2019 dan diakses pada tanggal 20 Maret 2020)

https://travel.detik.com/travel-news/d4664172/solo-traveling-jadi-tren-anakmilenial (dibuat pada tgl 13 Agustus 2019 dan diakses pada tanggal 10 Maret 2020 pada pkl 15.23)

https://travel.kompas.com/read/2019/04/09/0 80600527/sejarah-hotel-kapsulberawal-dari-jepang-kini-ada-diindonesia (dibuat pada tgl 19 April 2019 da diakses pada tgl 5 April 2020)

https://ravel.tempo.co/read/1089306/ini-2alasan-mengapa-solo-traveling-jaditrending/full\&view=ok (dibuat pada tgl 15 Mei 2018 dan diakses pada tanggal 18 Maret $2020 \mathrm{pkl} 20.15)$

https://www.cekaja.com/info/tren-traveling2019-mana-pilihamu/ (dibuat pada tgl 19 Februari 2019 dan diakses pada tgl 7 Apil 2020)

https://www.cnnindonesia.com/gayahidup/20181003195638-269-

335466/pariwisata-indonesia-masuk-10besar-dunia-versi-wttc (dibuat pada tgl 3 Oktober 2019 diakes pada tanggal 19 Februari 2020)

http://www.thefoodxplorer.com/hotelreview/capsule-hotel-old-batavia-jakartaindonesia/ (diakses pada tanggal 21 Mei 2020)

https://backpackerjakarta.com/review-oldbatavia-capsule-hotel-cikini/ (diakses pada tgl 21 Mei 2020)

https://www.tripadvisor.com/LocationPhoto DirectLink-g294229-d6833338-i120684973Capsule_Hotel_Old_Batavia-

Jakarta_Java.html (diakses pada tanggal 21 Mei 2020)

https://backpackerjakarta.com/review-oldbatavia-capsule-hotel-cikini/ (diakses pada tanggal 21 Mei 2020) 
(p-ISSN 1858-0112, e-ISSN 15537-37677)http://jurnal.unmuhiember.ac.id/index.php/wisata

https://www.trivago.co.id/en/jakarta-

92299/hotel/capsule-old-batavia-3369945

(diakses pada tanggal 21 Mei 2020)

https://www.traveloka.com/id-

id/hotel/indonesia/old-batavia-capsule-hotel$\underline{4000000464370}$ (diakses pada tanggal 21 Mei 2020) https://www.booking.com/hotel/id/capsuleold-batavia.html(diakses pada tanggal 21 Mei 2020) 